\title{
Development of ceramic production in the Kur River Basin (Fars, Iran) during the Neolithic. A compositional and technological approach using $\mathrm{X}$-ray fluorescence spectroscopy and thin section petrography
}

\author{
Possum Pincé ${ }^{1 a^{*}}$, Dennis Braekmans ${ }^{2,3}$, Negar Abdali $^{4}$, Ella De Pauw ${ }^{1 \mathrm{~b}}$, Sheler Amelirad ${ }^{3,5} \&$ Peter \\ Vandenabeele ${ }^{1}$ \\ $\left({ }^{1}\right.$ Ghent University $/{ }^{2}$ Cranfield University $/{ }^{3}$ Leiden University $/{ }^{4}$ University of Heidelberg $/{ }^{5}$ Shiraz \\ University of Arts)
}

\author{
*Corresponding author: Possum Pincé, possum.pince@ugent.be, +32 93310163 \\ ${ }^{1}$ a Department of Archaeology, Ghent University, Sint-Pietersnieuwstraat 35, B-9000 Ghent, Belgium \\ ${ }^{1 b}$ Department of Chemistry, Ghent University, Krijgslaan 281 S12, B-9000 Ghent, Belgium \\ ${ }^{2}$ Cranfield Forensic Institute, Cranfield University, Defence Academy of the United Kingdom, Faringdon Road, Shrivenham SN6 \\ 8LA, United Kingdom \\ ${ }^{3}$ Laboratory for Ceramic Studies, Leiden University, Einsteinweg 2, 2333 CC Leiden, The Netherlands \\ ${ }^{4}$ Prehistory and Near Eastern archaeology, University of Heidelberg, Sandgasse 7, 69117 Heidelberg, Germany \\ ${ }^{5}$ Department of Archaeology, Shiraz University of Arts, Shiraz, Iran
}

\begin{abstract}
:
This study aims to characterize the Neolithic ceramics (Mushki, Bashi and Jari wares) of the Kur River Basin and reconstruct the origin of the raw materials and manufacturing technology. Neolithic ceramics from thirteen different sites have been studied with handheld X-ray fluorescence spectroscopy (hXRF) and thin section petrography. The geochemical signature of these ceramics was defined and four compositional groups were determined. The variation in these compositional groups most likely relates to the ceramic wares for the Mushki and Bashi ceramics and to the site or group of sites for the Jari ceramics. Additionally, sediment samples were studied with hXRF demonstrating the variability in the geochemistry of the area. To determine the composition of the slips used for Bashi and Jari ceramics and to compare them with the inner fabric of the vessels, $\mu \mathrm{XRF}$ spectroscopy was applied. The combination of these archaeometrical techniques indicated the use of unaltered, fine-grained and mainly alluvial clays without the addition of temper (except for chaff) for the production of the three studied wares and the use of different clay types through the Neolithic in the Kur River Basin.
\end{abstract}

Keywords: Neolithic Iran - Petrography - Non-destructive XRF - Ceramic regional economies

\section{Acknowledgements}

We would like to express our gratitude to Prof. Dr. Holly Pittman and Katherine Blanchard of the Penn Museum (Philadelphia, USA) and Dr. Bruno Overlaet of the Royal Museums of Arts and History (Brussels, Belgium) for their valuable help and allowing us to study their collections. Additionally, we would like to thank Prof. Dr. De Dapper of Ghent University for his advice and help.

We are also grateful to the Belgian Science Policy Office (BELSPO), who funds this research project that is part of the BRAIN-project BArEO (Belgian Archaeological Expeditions to the Orient, Heritage in Federal Collections), BELSPO project no. BR/121/A3/BAREO.

Finally, we would like the reviewers for their useful comments and suggestions. 


\section{The Neolithic in the Kur River Basin}

The Mushki-Jari period of the Kur River Basin has first been discovered by Vanden Berghe in 1951-1952 by making several test trenches at Tall-i Mushki and Tall-i Jari B (Vanden Berghe 1952). In 1959, the Tokyo University Iraq-Iran Archaeological Expedition under the direction of Egami excavated at Tall-i Jari B (1959), Tall-i Jari A (1961, 1971) and Tall-i Mushki (1965). Unfortunately, only preliminary reports of the excavations in Tall-i Jari A and B remain (Egami and Masuda 1977; Maeda 1986; Nishiaki and Mashkour 2006). In more recent times, the Iranian Prehistoric Project further excavated at Tall-i Jari A and B (2003) and the Fars Archaeology Project started excavating at Tall-i Bashi (2003) (Alizadeh et al. 2004; Pollock et al. 2010). Additionally, important surveys were performed by Sumner in 1967-1969 locating archaeological sites in the basin. In 2003, a survey of Kushk-e Hezar under the direction of Alden took place and in 2016, the site Tang-e Khiareh was surveyed by Zeidi and his team (Alden et al. 2004; Sumner 1972; Zeidi et al. 2016). Despite these excavations and surveys, no pottery kilns or evidence of production could be located so far. Very little remains thus known about the production and distribution of these wares. This geochemical and petrographic study on Neolithic ceramics of the basin enables a characterization of the ceramics revealing aspects of their manufacturing technology and origin of the primary materials, and changes in these subjects through time. For this research, ceramics ${ }^{1}$ of the sites 405 (Tall-i Jaffarabad B), 348 (Tall-i Jari B), 3A0 (Tall-i Mushki), 566, 682 (Tall-i Chakhmaqi), 502 (Tall-i Ak), 5D6, 5E7, 5F4 (Tall-i Siyah, Gorbazdjun), 517, 520, 714 and 726 were studied (Sumner 1972) (Fig.1). This study is part of a larger project about the application of new analytical and petrographic techniques on Iranian ceramic collections from old excavations and surveys.

Fig.1 Map of the Kur River Basin with location of the studied Neolithic sites

The Neolithic in the Kur River Basin can be classified into three phases with their own cultural traditions: Mushki, Bashi and Jari. Each phase had a typical ceramic ware of which the name is the same as the period they appeared in and the site where the ware was found for the first time. The oldest Neolithic phase is the Mushki phase, dating from 6400 to 6050 cal. BCE (Nishiaki 2010). During this Mushki phase, the first ceramics in the Kur River Basin appear. This ceramic ware is a red slipped, burnished ware with a fine chaff-temper and dark painted decoration of geometrical motifs. The most common shape is the carinated bowl or jar that was decorated above the carination (Alden et al. 2004; Sumner 1972; Vanden Berghe 1952). A total of 13 Mushki-related sites are known, including those outside the basin in the regions of Kazerun, Shiraz and Sarvestan. The technological sophistication of this ware led to Sumner's idea that this knowledge was introduced by an immigrating population. The settlements in this period were widely scattered in the basin and located nearby big springs that rose near the valley edge (Nishiaki 2010, 2013; Sumner 1972, 1977; Zeidi et al. 2016). The sites were probably seasonal sites inhabited by a farmer population that used springs for irrigation and still partially relied on hunting and gathering activities (Hole 1987; Nishiaki 2010; Sumner 1972; Zeidi et al. 2016).

\footnotetext{
${ }^{1}$ The studied ceramics come from excavations of Vanden Berghe in the 1950s kept at the Royal Museums of Art and History (RMAH, Brussels, Belgium) and the Sumner and Alden collections of the Penn Museum (Philadelphia, USA).
} 
The consequent phase is a short transitional period named Bashi, dating around the turn of the $7^{\text {th }}$ to $6^{\text {th }}$ mill. BCE. During this phase, the Bashi ware developed. This ware has intermediate features of Mushki and Jari wares and consists of a dark painted decoration with designs such as the Bashi motif (Bernbeck 2010). More sedentary sites in the basin appeared and the restricted locations near springs faded suggesting the use of more irrigation practices in the arid plains. Whether or not irrigation occurred, subsistence farming became more important (Hole 1987; Nishiaki 2010; Sumner 1977).

During the Jari phase in the first centuries of the sixth millennium BCE, these processes further evolved and the people in the basin became sedentary (Nishiaki 2010). The typical Jari pottery of this phase appeared in a more restricted geographical area than the Mushki ware and was a thick and coarse ware with chaff-temper and painted decoration. The paint is generally flaky and dark but sometimes also reddish paint occurs. One of the painted designs is the ladder motif with slashes, which developed out of the Bashi motif and evolves later in that phase into the ladder with dots motif. Another typical Jari motif is the hook design. The vessels were coated in a layer of untempered, buff clay and occasionally a whitish slip was applied before firing. The occurrence of this white slip increased over time. The most common shapes are the high-sided bowls or beakers with vertical to slightly flaring sides and the decoration was generally applied on the upper and middle part of the vessel (Fig.2) (Alden 2004; Bernbeck 2010; Nishiaki 2010; Sumner 1972; Vanden Berghe 1952; Weeks et al. 2006; Potts et al. 2009).

Fig.2 Example of typical Mushki (left), Bashi (middle) and Jari (right) pottery from the RMAH and Penn collections

From the Mushki to the Jari phase, socio-economic changes occurred that are visible in changes in faunal assemblages, flint industries, subsistence patterns and the occurrence of less non-local materials such as shells and obsidian (Fukai et al. 1973; Mashkour et al. 2006; Nishiaki 2010). One of the factors that could have contributed to this fast cultural shift according to Nishiaki (2010) is the $8.2 \mathrm{ka}$ event (6200 cal. BCE). A global cooling and drying took place, which lasted for a few hundred years. Around the beginning of the Bashi/Jari phase, the climate ameliorated. This research will determine if also changes in ceramic production between the different phases are present.

\section{Geographical and geological framework}

The Kur River Basin is a large endorheic basin consisting of NW-SE mountain ranges and intermontane plains in the Zagros Simple Folded Belt, which is a structural subzone of the Zagros fold-thrust belt (ZFTB) (Alavi 2004; De Schacht et al. 2012; Moghadam and Stern 2011; Sepehr 2004). During the Palaeozoic, it was part of a large continental basin that underwent rifting in the Permo-Trias due to the opening of the Neo-Tethys Ocean between Arabia and Iran. Deposition of dolomite, limestone, evaporates, shale and marl accumulated (Sepehr 2004). In the subsequent Jurassic-Cretaceous, the basin was divided into the Luristan basin in the northwest and the Fars basin in the southeast. Both basins contained different sedimentary successions. In the Fars basin, mainly shallow marine sediments were deposited while the Luristan basin contained deeper water sediments (Sepehr 2004). The northeastward subduction of the Neo-Thethyan oceanic crust under the Iranian plate from the Upper Cretaceous onwards, led to the collision of the Arabian and Iranian plates in the Tertiary and the Luristan and Fars basin became one basin again. This created the folded, faulted and uplifted bedrock ridges of the Zagros of which mainly the Jurassic, Cretaceous 
and Tertiary formations are visible as anticlines representing different depositional environments. The bedrock units in our study area date from the (Jurassic and) Cretaceous periods (Alavi 2004; Minc 2016; Sepehr 2004). The Cretaceous Sarvak and Dariyan formations are the most abundant outcrops here. The youngest Sarvak Formation consists of medium bedded to massive grey limestone while the Dariyan Formation comprises grey to brown thick-bedded to massive orbitolina sandy limestone and argillaceous limestone. The other Kazhdumi, Gadvan, Fahliyan and Surmeh Formations are made of different types of limestone, dolomite, marl and shale (Afghah 2014; Geological survey of Iran 1971). Northeast of the study areas, in the Zagros Imbricate Zone, Mesozoic ophiolites crop out and older geological strata from Jurassic occur (Moghadam and Stern 2011). Further southwestwards, on the other hand, the younger Tertiary bedrock units are exposed.

The intermontane plains and foothills are filled with Quaternary material consisting of silt and clays from fluvial sedimentation and aeolian deposits that have been reworked by fluvial activities (Kehl et al. 2009). The upper sediments of the plain were deposited at a higher rate between 21000 and 7000 years ago, possibly due to a cooler and drier climate (Kehl et al. 2009). Previous research on lake cores elucidated that similar climatic conditions as today probably started around $4500 \mathrm{BP}$ (De Schacht et al. 2012; Stevens et al. 2001). Two main rivers are present in the study area, namely the Sivand and Kur river, which confluence around the site of Tall-i Sauz (29 51'39.59" N, $52^{\circ} 47^{\prime} 34.16$ " E). These rivers seem to have had an increased river incision between 10000 and 4000 years ago because of a mid-Holocene tectonic uplift in the lower part of the basin. This incision in the alluvial plain created a lower terrace, which decreases downstream (Kehl et al. 2009).

\section{Materials and methods}

\subsection{Samples}

The selected pottery was first classified into different wares based on their decoration style, technological features and surface treatment. A classification into subperiods could also be made based on the painted design types (Bernbeck 2010; Maeda 1986). The original vessel types or shapes, however, could only be determined for some of the diagnostic sherds and is thus limited. The archaeometrical techniques were executed autonomously whereafter the results were compared and integrated with the archaeological background. The code names of the ceramics mentioned in this paper are the inventory numbers of the museums. The 6-number codes derive from the Penn Museum (Philadelphia, USA) and the IR-codes from the Royal Museums of Art and History (RMAH) (Brussels, Belgium). An overview of the analyzed sherds with their inventory numbers, site, (sub)period, design type and the petrographic groups to which they belong (see infra) is presented in Table 1.

Table 1 List of the analyzed ceramics with additional information

Additionally, 33 samples from different alluvial and colluvial clay outcrops spread across the Kur River were studied (Fig.3). For the selection of these clays, several factors were taken into account. A first criterium was the distance of the possible clay source from the production site. Based on ethnographic evidence, clay procurement was mostly performed in a radius of about $7 \mathrm{~km}$ from the site (Arnold 1988). In addition, there was a focus on the areas around the sites where evidence of production had been found in pre-Islamic times, namely Tall-i Malyan, Kaftari kiln site, Tall-i 
Bakun, Tall-i Qaleh and Tall-i Darwazeh, and on the differing nature of the clay. The selected samples consisted of alluvial and colluvial clay outcrops from different geological substrates in order to cover the different clay types in the surrounding of the sites. Finally, the location depended on the field circumstances such as cuts in the landscape, road conditions and time but the chosen sediments originate from ceramic-suitable clay-rich deposits. The coordinates of the sample locations are listed in Table 3.

Fig.3 Location of the clays that were analyzed with hXRF

\subsection{Thin section petrography}

The sample selection $(n=24)$ for thin sectioning was based on the macroscopic classification into different wares (and thus phases) and the site where the sample was found in order to obtain a representative selection. In addition, the selection also depended on the museum approval and the size of the sample. Thin section petrography is used as a main technique for classifying ceramics according to their mineralogical composition and general texture. Petrographic analysis of thin sections has been a major established technique in the past decades to characterize and identify ancient ceramics from all over the world (Braekmans et al. 2017; Dickinson and Shutler 2000; Quinn et al. 2017; Reedy 2008; Ting and Humphris 2017). The samples selected here for petrographic analysis are analyzed for traces of technological developments as well, such as potential temper selection and fire temperature assessment (Braekmans and Degryse 2016; Quinn 2013). Thin section analysis was conducted on both a Leica DM750P and an Olympus BX41 microscope. Thin section description and grouping methodology concentrated on the presence and size of the non-plastic inclusions as well as the optical properties of the clay matrix. Groups are denominated based on the main technological or compositional features.

\subsection{Handheld X-ray fluorescence spectroscopy $(h X R F)$}

A total of 76 ceramic samples were studied with handheld X-ray fluorescence spectroscopy (hXRF) to identify the elements present in the samples and determine different compositional groups. The non-destructive nature of this technique is very useful since the studied ceramics are part of museum collections that sometimes cannot be sampled.

The handheld X-ray measurements were performed with the commercial instrument Olympus Innov X Delta Premium positioned in a lab stand. Three different spots per sample (and two spots on each of the RMAH samples) were measured with two different modes in the rhodium (Rh) based $\mathrm{X}$-ray tube. The first measurement mode with aluminum (Al) filter was executed in air for $150 \mathrm{~s}$ (live time) with a voltage of $40 \mathrm{kV}$ and a current of $38.7 \mu \mathrm{A}$. This mode is optimal for measuring the higher Z-elements from V onwards. The second mode (no filter) was used for measuring the low Z-elements from $\mathrm{Mg}$ to $\mathrm{Mn}$. These measurements were also performed in air for $150 \mathrm{~s}$ (live time) but with a voltage of $10 \mathrm{kV}$ and a current of $50.8 \mu \mathrm{A}$. This provided a polychromatic beam of $5 \times 5 \mathrm{~mm}^{2}$ to excite the targeted ceramic sample in front of the probe head. A silicon drift detector (SDD) detected the emerging X-ray fluorescence.

The spectral data were consequently processed by the XRF-spectrum evaluation software AXIL (Analysis of X-ray spectra by Iterative Least Squares), which enables the deconvolution of complex 
spectra (Van Espen et al. 1986; Vekemans et al. 1995). For further processing of the data, the net peak X-ray intensities were used. No reliable concentrations could be calculated since no dedicated standards are available for the analysis of this type of ceramics.

The measurements on the ceramics were performed on flat and clean breaks. Three (and sometimes two) measurements with both modes were performed per sample to compensate for the heterogeneity of the ceramic material. The measurements of the Penn samples were performed on fresh breaks, while the RMAH ceramics needed to be analyzed on old breaks. The sediment samples were fired in an oven at $80^{\circ} \mathrm{C}$ for two days to evaporate the water whereafter clay pellets of $2 \mathrm{~cm}$ diameter were made to obtain a flat surface. Three measurements with both modes per pellet were conducted to consistently compare them with the ceramic results.

Bivariate plots were made to determine the different compositional groups. The selection of elements used for these bivariate plots was based on their discriminating ability. To compare the composition of the ceramics and clay samples, principal component analysis (PCA) was chosen as multivariate statistical method. To perform this, first the square root of the net peak intensities of the selected elements is taken whereafter they are normalized. For this, the in-house software MICROXRF2 was applied (Vekemans et al. 1995).

\subsection{Micro X-ray fluorescence spectroscopy $(\mu X R F)$}

Laboratory non-destructive $\mu \mathrm{XRF}$ experiments on fresh breaks of the slips and inner fabrics of 2 Bashi and 3 Jari wares were performed using the Eagle-III microprobe (EDAX, Inc., Mahwah, NJ, USA), a scanning $\mu$-XRF spectrometer, to determine the composition of the clays used for the slips and compare this to the underlying fabric of the vessel. The Eagle-III uses a rhodium $\mu$-X-ray tube and a liquid nitrogen cooled energy dispersive $\mathrm{Si}(\mathrm{Li})$ - detector with an active detector area of 80 $\mathrm{mm}^{2}$. Maximum efficiency is achieved with a tube voltage of $40 \mathrm{kV}$ and a tube current corresponding to a $30 \%$ dead time. The beam size was adjusted to the minimum value of $30 \mu \mathrm{m}$ and to allow the detection of low Z-elements (down to $\mathrm{Na}$ ) the measurements were executed in a vacuum environment. Quantification of the point measurements was performed by a fundamental parameter based standardless method, which is equipped in the EDAX Eagle-III software package. The $\mu$-XRF experiments were performed on flat and clean breaks, in like manner as with the hXRF measurements. Principal component analysis was performed on the quantified results for comparison of the slips and underlying fabrics of the samples.

\section{Results}

\subsection{Petrography}

Petrographic analysis of a selection of the potsherds resulted in the determination of 6 petrographic groups and one individual outlier. The characteristics of these groups can be reviewed in Table 2. Each of these groups were allocated to a general geological substrate based on the relative quantities and presence of different mineral components. The different groups show that weathered sedimentary rock formations, including carbonate rich deposits, are the main geological substrate for these ceramic materials. Igneous and metamorphic rocks are all but absent in this particular dataset. Nevertheless, few small crystals were identified in one individual Jari ware sample of site 682 (sample 85-61-105). The fine grained texture of the fabrics indicate the use of eroded, 
secondary clays, which can come from the alluvial plains or foothills of the carbonate rock formations. The fabrics are generally characterized with 15 to $25 \%$ voids consisting of irregular small to large vughs, some vesicles and (fine) planar voids that are quite well oriented with the vessel margins. These voids seem to mainly derive from burned out plant matter and reflects the use of chaff temper. Some of the voids were partially infilled with secondary calcite during the burial of these ceramics. These post-depositional alterations of calcite deposition within the voids or dissolution of calcite inclusions caused the element calcium to be discarded as an element used for the bivariate plots and multivariate statistical analysis of the XRF data to avoid 'false' groupings. Occasionally, voids appear that were originally composed of carbonate materials in general, crinoids or shells. The grain-size distribution is unimodal and no particular orientation for the inclusions seems to be present. Varying amounts of carbonate materials, chert, biotite, muscovite and nodules with the clay provide a systematic overview. In some of the samples, a low number of clay pellets occur.

The first three petrographic groups can be easily discerned in the region through the presence of an abundant number of carbonate materials. Especially the presence of large grains of limestone and a dominant presence of smaller calcite grains are typical for this group of sherds. While the general characteristics of these three varieties remain identical, there is a difference in the used clays. The 'Carbonate-chert' group ( $\mathrm{n}=3)$ comprises, besides the calcite and limestone fragments, several subangular chert fragments $(100-250 \mu \mathrm{m})$. The other, most likely natural, inclusions consist of small quartz crystals, biotite and muscovite micas, plagioclase and alkali feldspar and Fe-oxides. The 'Carbonate-limestone I' group, on the other hand, can be distinguished from the second carbonate-limestone group by its occasional presence of various fossil fragments (i.e. crinoids, bivalves) and mudstones, and its calcareous matrix. Few small microcrystalline quartz, biotite and muscovite micas and Fe-oxides are also present. The 'Carbonate-limestone II' variety is remarkable for its non-calcareous matrix with larger limestone fragments and a higher presence of quartz combined with a sporadic presence of biotite, muscovite and Fe-oxides.

The other three petrographic groups have a fabric with less carbonate minerals, especially in the matrix. The 'Sedimentary I: melange' group consists of a fine-grained microcrystalline matrix with few calcite grains, small quartz crystals, some Fe-oxides, biotite and muscovite micas and alkali feldspar. Chert fragments (around $200 \mu \mathrm{m}$ ) can also occur. The 'Sedimentary II: sintered' group, on the other hand, is recognized by its more thorough and systematic sintered matrix. The presence of primary calcite inclusions in this group could indicate a firing temperature of max. $850-900^{\circ} \mathrm{C}$. Therefore, this particular sintering is probably not the consequence of a higher firing temperature but of a very fine grained texture $(<50 \mu \mathrm{m})$ with less and smaller carbonate minerals and potentially a prolonged firing procedure. Besides the typical presence of some small quartz, Fe-oxides, biotite mica and occasional alkali feldspar minerals, rare fossil fragments are sometimes still recognizable. Finally, the last group "Sedimentary III: mica" is characterized by a significant enrichment in small euhedral biotite grains throughout the matrix. Calcite and quartz are the dominant (10-20\%) inclusions but also some accessory Fe-oxides, muscovite mica and occasional mudstone can be attributed to this group.

One sample could not be readily classified into any of the above described groups. This sample has a rather carbonate-rich matrix combined with a small number of chert and volcanic fragments, such as small euhedral pyroxene minerals $(<200 \mu \mathrm{m})$. In addition, small calcite, quartz, Fe-oxides and some biotite and muscovite micas could be identified (Fig.4). 
Table 2 Characteristics of the different petrographic groups and outlier

Fig.4 Thin section photomicrographs of selected ceramics from each petrographic group: (a) Chert-carbonate; (b) Limestone I; (c) Limestone II; (d) Sedimentary I: melange; (e) Sedimentary II: sintered; (f) Sedimentary III: mica and (g) Individual (outlier).

Handheld XRF is consequently applied to see if the determined petrographic groups can be verified and additional patterns in chemical composition can be identified.

\section{2 hXRF analysis}

A total of 19 elements could be detected with hXRF after processing the 221 measurements per mode in AXIL, namely Al, Si, S, K, Ca, Ti, Cr, Mn, Fe, Ni, Cu, Zn, Ga, As, Rb, Sr, Y, Zr and Nb. These elements were present in all the analyzed ceramic samples so no difference in the occurrence of certain elements was detected. To compare the intensities of these elements, a normalization over the intensity of $\mathrm{Si}$ was performed. For the bivariate plots, the data points per measurement were used in order to see the heterogeneity of the ceramic samples and possible outliers.

Four compositional groups could be identified in the bivariate plots of $\mathrm{Sr} / \mathrm{Si}-\mathrm{Zr} / \mathrm{Si}$ and $\mathrm{Sr} / \mathrm{Si}-\mathrm{Cr} / \mathrm{Si}$. The first group consists of a high intensity of $\mathrm{Zr}$ and a lower intensity of $\mathrm{Sr}$ compared to the second group. The ceramics that can be attributed to this first group are the Mushki ceramics from different sites and the Jari ceramics from site 726. The second group, on the other hand, has a higher intensity of $\mathrm{Sr}$ and a lower intensity of $\mathrm{Zr}$. The Bashi ceramics from different sites and the Jari ceramics from sites 502 and 5E7 occur in this group (Fig.5). The Jari ceramics of site 682 can be classified in a compositional group (group 4) with a higher intensity of $\mathrm{Cr}$ in comparison to the other groups (Fig.6). The remaining Jari ceramics from sites 517, 405, 520 and 5D6 can be attributed to a last compositional group (group 3). Site 405 appears to be a subcluster in this group with a composition that is less similar in comparison to the composition of the Jari ceramics from sites 517, 520 and 5D6. The ceramics of this group have intermediate intensities of $\mathrm{Sr}$ and $\mathrm{Zr}$ compared to group 1 and 2 and a lower intensity of Cr than group 4. Outliers 85-61-140 (Jari ware, site 566) and IR.2136 (Mushki ware, site 3A0) have an even higher presence of $\mathrm{Zr}$ than the ceramics of group 1.

Fig.5 Three compositional groups are visible on the bivariate plot of $\mathrm{Sr} / \mathrm{Si}$ vs $\mathrm{Zr} / \mathrm{Si}$ with classification into different sites and ceramics

Fig.6 Bivariate plot of $\mathrm{Sr} / \mathrm{Si}$ vs $\mathrm{Cr} / \mathrm{Si}$ with compositional group 4 (= Jari ware from site 682)

The $\mathrm{Sr} / \mathrm{Si}-\mathrm{Zr} / \mathrm{Si}$ bivariate plot thus reveals a correlation between the Mushki ceramics and the first chemical group, and the Bashi ware and the second chemical group, which is even clearer in Fig.7. The Jari ceramics, on the other hand, cannot be attributed to one compositional group since much variability occurs in the intensities of the elements present. There is, however, a difference notable in the composition of Jari ware depending on the sites where they were found. Plots with a classification into different shapes or decoration motifs related to the subperiod did not reveal any compositional grouping.

Fig.7 Bivariate plot of $\mathrm{Sr} / \mathrm{Si}$ vs $\mathrm{Zr} / \mathrm{Si}$ with classification into the different wares 
The hXRF analysis of 33 clay samples determined the same 19 elements that were detected in the ceramic samples. These elements were present in all the analyzed clay samples except for sample 26 in which no Y, Zr or Nb could be detected. Consequently, this sample was not implemented in the bivariate plot of $\mathrm{Sr} / \mathrm{Si}$ versus $\mathrm{Zr} / \mathrm{Si}$ and in the PCA analysis of the ceramic and clay samples, presented in the discussion. Also here, a normalization over the intensity of Si was conducted to compare the intensities of the elements. The bivariate plots of $\mathrm{Sr} / \mathrm{Si}-\mathrm{Zr} / \mathrm{Si}$ (Fig.8) and $\mathrm{Sr} / \mathrm{Si}-\mathrm{Cr} / \mathrm{Si}$ (Fig.9) present a difference in the elemental composition of the clay from the alluvial plain and the clay from the foothills of the Zagros mountains. Both bivariate plots also indicate a similar elemental composition of the clay samples from different spots along the river streams. Therefore, the clays from along the Sivand and the Kur river above the junction with the Sivand river are indistinguishable with hXRF from the clay along the Kur river below the junction. Sample 12 is an alluvial clay from near the site of Tall-i Malyan and is an outlier in both bivariate plots since it comprises more $\mathrm{Sr}$ than the other analyzed clay samples from the basin. A higher presence of $\mathrm{Sr}$ is also present in sample 26 on plot $\mathrm{Sr} / \mathrm{Si}$ vs $\mathrm{Cr} / \mathrm{Si}$. Both outliers demonstrate the differentiation in the alluvial clays, especially sample 26, which clearly has a different composition than the other alluvial clays since it also lacks a detectable amount of $\mathrm{Y}, \mathrm{Zr}$ and $\mathrm{Nb}$. Although the alluvial group can be attributed to another compositional group than the colluvial group, still quite some variability in the composition of the clays from this alluvial group exists. The last sediment sample that differs from the two defined compositional groups is sample 19 because of its higher $\mathrm{Cr}$ presence. This sample derives from a foothill near the Kaftari kiln site. The intensities of the elements used for the bivariate plots and PCA are listed in Table 4.

Fig.8 Bivariate plot $\mathrm{Sr} / \mathrm{Si}$ vs $\mathrm{Zr} / \mathrm{Si}$ of the sediment samples presenting a difference in composition between the colluvial and alluvial clays

Fig.9 Bivariate plot $\mathrm{Sr} / \mathrm{Si}$ vs $\mathrm{Cr} / \mathrm{Si}$ of the sediment samples presenting a difference in composition between the colluvial and alluvial clays and three outliers

\section{$4.3 \mu X R F$ analysis}

The $\mu$ XRF experiments on the slips and inner clay of two Bashi and three Jari sherds detected 18 elements, i.e. $\mathrm{Mg}, \mathrm{Al}, \mathrm{Si}, \mathrm{P}, \mathrm{S}, \mathrm{K}, \mathrm{Ca}, \mathrm{Ti}, \mathrm{Cr}, \mathrm{Mn}, \mathrm{Fe}, \mathrm{Ni}, \mathrm{Cu}, \mathrm{Zn}, \mathrm{Ga}, \mathrm{Rb}, \mathrm{Sr}$ and Zr. The concentrations from the corresponding oxides could be obtained from the Eagle-III software and $\mathrm{MgO}, \mathrm{Al}_{2} \mathrm{O}_{3}, \mathrm{SiO}_{2}, \mathrm{~K}_{2} \mathrm{O}, \mathrm{TiO}_{2}, \mathrm{Cr}_{2} \mathrm{O}_{3}, \mathrm{MnO}, \mathrm{Fe}_{2} \mathrm{O}_{3}, \mathrm{Rb}_{2} \mathrm{O}, \mathrm{SrO}$ and $\mathrm{ZrO}_{2}$ were applied in PCA to determine possible trends in the slips and clays from different sites and wares that can be related to provenance and manufacture technology. The first two principal components explain 62.976\% of the total variance. The preliminary results, presented in Fig.10, indicate that some slips have a similar composition as the underlying clay (samples 85-61-123 and 85-61-134) while other slips have a much higher concentration of $\mathrm{Cr}$ (sample 85-61-104), Sr (sample 85-61-146) or K (sample 85-61-128) than its underlying fabric. The slips of the Bashi ware from sites 3A0 and 517 and the slip of the Jari sample from site 726 can be attributed to the same "compositional group". Moreover, the inner clays of the Bashi sample from site 517 and the Jari sample of site 726 are also similar to the clays used for application of their slip layer. Based on these preliminary results, the used clays of the Bashi and especially the Jari vessels seem to be quite similar, while the composition of the slips can differ from the inner clay of the vessels. The high Cr-group visible in the hXRF bivariate plot of the ceramic samples could also be determined here. This $\mu$ XRF analysis revealed that the 
presence of $\mathrm{Cr}$ was even higher in the slip than in the inner clay of the sample. However, analysis of a larger dataset is necessary to evaluate these first results.

Fig.10 Score plot (a) and loading plot (b) of the PCA on the $\mu$ XRF data presenting the differences between slips and clays from different ceramic wares and sites

\section{Discussion}

\subsection{Comparison of the ceramics and raw materials}

To compare the analytical data of the ceramic samples with the analyzed clays, PCA was performed using the intensities of elements $\mathrm{Al}, \mathrm{Si}, \mathrm{K}, \mathrm{Ti}, \mathrm{Cr}, \mathrm{Mn}, \mathrm{Fe}, \mathrm{Rb}, \mathrm{Sr}$ and $\mathrm{Zr}$. The first two principal components explain $74.54 \%$ of the total variance. The score plot (Fig.11) of these principal components shows a similarity in the composition of the Mushki ceramics and the alluvial clays indicating the use of local alluvial clays for the production of Mushki ware. The Bashi ceramics, on the other hand, have different composition than the analyzed alluvial clays but their composition lies more or less within the outlines of the different analyzed clay compositions of the basin suggesting the use of local clays for the production of the Bashi ceramics. Additionally, the composition of the Bashi ceramics is still more related to the alluvial samples than to the analyzed colluvial material from the foothills. The following Jari phase consisted of ceramics with a large variability in composition that, however, also fits within the compositional boundaries of the analyzed local clays.

The outlier 85-61-140, determined in the bivariate plots of the hXRF results, has a similar composition as the analyzed colluvial clays. Probably, a colluvial clay was used for the production of this vessel. A high amount of $\mathrm{Cr}$ is present in the Jari ceramics of site 682 and the colluvial clay sample 19. The location of this clay is near site 682 so the clay procurement of Jari ware from site 682 might have taken place in the vicinity of the site.

Fig.11 Score plot (a) and loading plot (b) of the PCA on the hXRF data of the ceramic and sediment samples showing a similarity in composition between the Mushki ware and alluvial

clays.

\subsection{Production technology and types of raw material sources}

This assemblage of ceramics is outstanding for its use of fine-grained and well sorted clays. The presence of overall fine and small inclusions in the clay used for ceramic production can be naturally part of the clay or be the result of levigation. For these ceramics it is most likely part of the clay source since also some larger limestone fragments are still present that would otherwise have been removed. The number of these coarser grains is, however, too low to be added as temper. The small aplastic inclusions are mostly subrounded and no bimodal grain size distribution in the ceramics is visible that can point to the addition of temper. Moreover, the calcite grains are often weathered into microcrystalline calcite (micrite). All this indicates the use of unaltered but finegrained clays. The only temper that was added to the clays is chaff of which the amount in the vessels is quite variable. This temper was most likely used to create more solidity to enable the manufacture of larger vessels. This indicates a limit in the potters' production technology obstructing the full exploitation of these fine-grained, good quality clays. This area consists of 
many qualitative clay outcrops that nowadays are exploited and manufactured without the addition of any temper. In few sherds, some voids might resemble crinoids or shells that might suggest the use of a different calcium carbonate deposition.

From macroscopic study it is clear that a red burnish for the Mushki ware and buff slips for the Bashi and Jari wares were often used as finishing techniques, whereafter the decoration was painted on the sherds. The preliminary study of $\mu$ XRF on the slips of several Bashi and Jari ceramics, moreover, revealed that the slips can have a similar or differing composition than the inner clays, so no uniform slip seems to have been used. The firing of the ceramics occurred at a max. temperature of $850^{\circ} \mathrm{C}$. Higher firing causes sintering and break down of the primary calcite, which is still present in the studied ceramics. The sintered matrix of the 'Sedimentary II: sintered' group, however, was most likely not fired at a higher temperature. The presence of calcites in the sintered matrix suggests an use of an originally very fine-grained clay. For the production of this group, clays along rivers might have been used since these are very fine grained. One of the clay outcrops used for the production of Bashi and Jari wares might thus be located near the river in the vicinity of the production site. However, the three river clay samples that were analyzed with hXRF do not match with the composition of the ceramics from the 'Sedimentary II: sintered' group. The geographical distribution of the 'Sedimentary II: sintered' group samples was widespread in the basin so possibly another river course or tributary might have been used. Furthermore, this petrographic group appears in both Bashi and Jari periods although the frequency of appearance and the distribution was higher in the Bashi period based on the studied samples. The 'Sedimentary II: sintered' group, on the other hand, was only determined in Jari ceramic samples from two sites (520 and 3A0) in this dataset (Fig.12)

Besides information about the production technology of the ceramics, the petrographic groups might also indicate differences in used clay types and thus provenance. The differential presence of chert and fossil fragments in the carbonate groups suggests the selection of different clays with a Ca-rich carbonate provenance in the region. The 'Sedimentary III: mica' group with its euhedral biotite flakes, is probably related to a different clay outcrop than the other petrographic groups. The hXRF analysis on the ceramics of the 'Sedimentary III: mica' group, moreover, showed a similarity in the elemental composition of these ceramics. Finally, the systematic presence of mafic minerals such as pyroxene in the 'Individual' sample 85-61-105 is rather unexpected in this assemblage of ceramics. Analysis of the geology in the broader area indicates that ophiolitic outcrops about $120 \mathrm{~km}$ north of the basin might have been a possible source for clay type used for the production of these ceramics. The analytical data supports this possible ophiolithic influx since a much higher amount of $\mathrm{Cr}$ was present in this sample compared to the other ceramics (see $\mathrm{hXRF}$ group 4). This different elemental and mineralogical composition might thus suggest that this fabric or the clay originates from outside the Kur River Basin. However, it must be kept in mind that still many aspects of the regional geology or the distribution of the Jari ceramics remain unknown.

The combination of the analytical and petrographic data further reveals that the Mushki ceramics only appear in the petrographic carbonate groups. The Bashi and especially the Jari ware can be attributed to both carbonate and sedimentary groups. It is notable that a discrepancy occasionally exists between the petrographic and chemical groups. While the level of potential interpretation may vary, petrographic grouping procedures were mainly geared towards technological practices (e.g. sintered and fine-grained groups) rather than on the basis of variation in mineral components (of which the range is relatively restricted). The potential of hXRF, on the other hand, is pointed 
more at defining an average (or bulk) geochemical signal of the different ceramics available. This discrepancy clearly indicates a significant amount of variation that is present within the larger geographic area and it is therefore important to assess and characterize this variability as extensive as possible. In this way a reference framework and documentation of this variability for these types of ceramics in the larger region can further be constructed on both a petrographic and chemical scale.

\subsection{Possible patterns of ceramic interaction}

The hXRF analysis allowed for the determination of two large compositional groups, namely group 1 comprising the Mushki ceramics and group 2 that contains the Bashi ware. No differences in composition between sites could be notified for these two wares (Fig.13). Possibly, these wares were each made in one or more production centers in the same region from where it was exchanged or taken with the still partly mobile population to different places. Different alluvial clay sources might have been used for the Mushki ceramics. Whether this hypothesis can be verified or not, the Bashi period, that is generally seen as a short transitional phase, had a ceramic type with a distinctive clay composition that differed from the preceding and following period.

The composition of the Jari ware is quite variable and correlations between the composition of the ceramics and the sites or group of closely located sites are found (Fig.13). A possible explanation is the manufacturing of Jari ceramics at site level using local clays in the vicinity of these sites. Kilns or other evidence of ceramic production activities are necessary to further elucidate possible production and distribution patterns. However, the cultural changes from the Mushki to Jari period visible in faunal assemblages, flint industries, the occurrence of non-local materials and sedentary patterns seem to be reflected in the ceramic production as well. The decrease of interactions with other regions during the Jari period might also be present between the different sites in the basin of the now sedentary population.

\section{Conclusions}

The combination of petrographic and analytical techniques allowed for a characterization of production practices of the Neolithic ceramics of the Kur River Basin. The thin section petrography mainly contributed to the understanding of the pottery technology and textural composition in the different phases. The 'Individual' thin section sample, however, consisted of more 'exotic' inclusions suggesting an influx of material from an ophiolitic source indicating the possible provenance of this material. For the production of the Mushki, Bashi and Jari wares, unaltered but exceedingly fine-grained clays seem to have been used with only an addition of different amounts of chaff temper to improve the solidity of the vessels. The small inclusions in the ceramics were thus naturally part of the primary material, making the bulk hXRF data in this case a reliable tool for exploring the extent of variable resource utilization and provenance.

The analyzed clay samples demonstrated a differential composition between the alluvial and colluvial clays and heterogeneity in the composition of the alluvial clays in the basin, which is larger than previously assumed. However, it remains difficult to pinpoint the exact provenance of the material for now. For this, first production sites need to be found whereafter the possible clay sources for ceramic production in the vicinity of these sites can be sampled. The combined ceramic and sediment data indicated the use of alluvial clays for the production of Mushki ceramics. In the 
subsequent phase, a different clay type or mixture of types was used for the production of the Bashi ware. These clays differed from the alluvial clay samples but were still more related to them than to the colluvial samples. For the Jari ceramics, no systematic clay type could be determined. The used clay source was more likely related to the site where the ceramic was found. The variations in the raw material selection and its relation to the sites or wares indicate a fairly elaborate change in production and possible exchange patterns during the different Mushki, Bashi and Jari phases.

\section{References}

Afghah M, Haghighi AS (2014) Aptian biostratigraphy in South Zagros Basin, Southwest Iran. Geoscience Frontiers 5:277-288

Alavi M (2004) Regional stratigraphy of the Zagros Fold-Thrust Belt of Iran and its proforeland evolution. American Journal of Science 304:1-20

Alden JR, Abdi K, Azadi A, Biglari F, Heydari S (2004) Kushk-e Hezar: A Mushki/Jari period site in the Kur River Basin, Fars, Iran. Iran 42:25-45

Alizadeh A, Zeidi M, Askari A, Niakan L, Atabaki A (2004) Iranian Prehistoric Project Excavations at Tall-e Bakun A and B, Jari A and B, and Mushki: Reconstruction of the prehistoric environment in Marvdasht. The University of Chicago Press, Illinois

Arnold DE (1988) Ceramic theory and cultural process. Cambridge University Press, Cambridge

Bernbeck R (2010) The Neolithic pottery. In: Pollard AM, Bernbeck R and Abdi K (eds) The 2003 excavations at Tol-e Basi, Iran: Social life in a Neolithic village, Verlag Philipp Von Zabern, Mainz, pp 65-151

Braekmans D, Degryse P (2016) Petrography: Optical Microscopy. In: Hunt AMW (ed) The Oxford handbook of archaeological ceramic analysis, Oxford University Press, Oxford, pp 233-265

Braekmans D, Degryse P, Neyt B, Waelkens M, Poblome J (2017) Reconstructing regional trajectories: the provenance and distribution of Archaic to Hellenistic ceramics in Central Pisidia (South-west Turkey). Archaeometry 59(3):472-492

De Schacht T, De Dapper M, Asadi A, Ubelmann Y, Boucharlat R (2012) Geoarchaeological study of the Achaemenid dam of Sad-i Didegan (Fars, Iran). Géomorphologie: relief, processus, environnement 1:91-108

Dickinson WR, Shutler R (2000) Implications of petrographic temper analysis for oceanian prehistory. Journal of World Prehistory 14(3):203-266

Egami N, Masuda S (1977) Tal-i Jarri A: A preliminary report of the excavations in Marv Dasht, 1961 and 1971. Orient 13:1-7

Fukai S, Horiuchi K, Matsutani T (1973) Marv-Dasht III: The excavation at Tall-i Mushki, 1965. Yamakawa, Tokyo

Geological Survey of Iran (1971) Sivand, Saadatshahr, Shiraz and Arsenjan sheets. Geological map of Iran 1:100 000

Hole F (1987) Settlement and society in the village period. In: Hole F (ed) The archaeology of Western Iran: Settlement and society from prehistory to the Islamic conquest, Smithsonian Institution Press, Washingtion DC, pp 79-106

Kehl M, Frechen M, Skowronek A (2009) Nature and age of Late Quaternary basin fill deposits in the basin of Persepolis/Southern Iran. Quaternary International 196:57-70

Maeda A (1986) A study on the painted pottery from Tape Djari B. Bulletin of the Ancient Oriental Museum 8:55-86 
Mashkour M, Mohaseb A, Debue K (2006) Towards a specialized subsistence economy in the Marvdasht Plain: Preliminary Zooarchaeological Analysis of Mushki, Jari B, Jari A and Bakun A. In: Alizadeh A (ed) The origins of state organizations in Prehistoric highland Fars, Southern Iran: Excavations at Tall-i Bakun (OIP 128), University of Chicago Press, Chicago, pp 215-229

Minc LD (2016) Trace-element analyses of Uruk ceramics: Establishing a database to track interregional exchange. Journal of Archaeological Science: Reports 7:798-807

Moghadam HS, Stern RJ (2011) Geodynamic evolution of Upper Cretaceous Zagros ophiolites: Formation of oceanic lithosphere above a nascent subduction zone. Geological Magazine 148(5-6):762-801

Nishiaki Y (2010) A radiocarbon chronology for the Neolithic settlement of Tall-i Mushki, Marv Dasht Plain, Fars, Iran. Iran: Journal of the British Institute of Persian Studies 48:1-10

Nishiaki Y (2013) Mushki, Tall-e. Encyclopaedia Iranica online. http://www.iranicaonline.org/articles/mushki-site. Accessed 7 July 2017

Nishiaki Y, Mashkour M (2006) The stratigraphy of the Neolithic site of Jari B, Marv Dasht, Southwest Iran. Orient-Express 3:77-81

Pollock S, Bernbeck R, Abdi KE (2010) The 2003 excavations at Tol-e Basi, Iran: Social life in a Neolithic village (Vol. 10). Verlag Philipp Von Zabern, Mainz

Potts DT, Roustaei K, Weeks LR, Petrie CA (2009) The Mamasani district and the archaeology of southwestern Iran. In Potts DT, Roustaei K, Petrie CA and Weeks LR (eds) The Mamasani archaeological project stage one: A report on the first two seasons of the ICAR - University of Sydney expedition to the Mamasani district, Fars province, Iran (BAR International series S2044), Archaeopress, Oxford, pp 1-16

Quinn PS (2013) Ceramic petrography: The interpretation of archaeological pottery and related artefacts in thin section. Archaeopress, Oxford

Quinn PS, Zhang S, Xia Y, Li X (2017) Building the terracotta army: Ceramic craft technology and organisation of production at Qin Shihuang's mausoleum complex. Antiquity 91 (358):966-979

Reedy CL (2008) Thin-section petrography of stone and ceramic cultural materials. Archetype Books, London

Sepehr M, Cosgrove JW (2004) Structural framework of the Zagros Fold-Thrust Belt, Iran. Marine and Petroleum Geology 21:829-843

Stevens LR, Wright Jr HE, Ito E (2001) Proposed changes in seasonality of climate during the Late glacial and Holocene at Lake Zeribar, Iran. The Holocene 11(6):747-755

Sumner WM (1972) Cultural development in the Kur River Basin, Iran: An archaeological analysis of settlement patterns. Dissertation, University of Pennsylvania

Sumner WM (1977) Early settlements in Fars Province, Iran. In: Levin LD and Young TCJ (eds) Mountains and Lowlands: Essays in the archaeology of Greater Mesopotamia, 7th edn. Undena, Malibu, pp 291-305

Ting C, Humphris J (2017) The technology and craft organisation of Kushite technical ceramic production at Meroe and Hamadab, Sudan. Journal of Archaeological Science: Reports 16 (Supplement C):34-43

Van Espen P, Janssens K, Nobels J (1986) AXIL-PC: Software for the analysis of complex X-ray spectra. Chemometrics and Intelligent Laboratory Systems 1:109-114

Vanden Berghe L (1952) Archeologische opzoekingen in de Marv Dasht vlakte (Iran). Jaarbericht Ex Oriente Lux 12:211-220 
Vekemans B, Janssens K, Vincze L, Adams F, Van Espen P (1995) Comparison of several background compensation methods useful for evaluation of energy-dispersive X-ray fluorescence spectra. Spectrochimica Acta Part B 50(2):149-169

Weeks L, Alizadeh K, Niakan L, Alamdari K, Zeidi M, Khosrowzadeh A, McCall B (2006) The Neolithic Settlement of Highland SW Iran: New evidence from the Mamasani District. Iran 44:1-31

Zeidi M, Zarqani SH, Conard NJ (2016) Tang-e Khiareh: A newly discovered Neolithic site in the Kur River Basin of Fars Province, Iran. In: Roustaei K and Mashkour M (eds) The Neolithic of the Iranian Plateau: Recent research, Ex Oriente, Berlin, pp 217-226

Table 3 List of the analyzed clay samples, their locations and classification Table 4 List of the net peak intensities of the elements used for the bivariate plots and PCA 